\title{
Records of Surface Meteorological Elements and their Applications in Alexandria Eastern Harbour, Egypt
}

\author{
By Tarek M. El-Geziry*
}

\begin{abstract}
The surface meteorological elements, namely: air temperature, wind regime (speed and direction), dew point temperature, relative humidity and atmospheric pressure were considered; to describe the general meteorological conditions over Alexandria Eastern Harbour (AEH). These conditions were then applied to calculate some important physical properties of the Harbour's surface waters: sea surface temperature (SST), the evaporation rates and the net surface heat flux. The period of investigation extended from 01.01.2019 to 31.12.2020. The air temperature distribution over AEH reflected a seasonal variability with higher values in spring/summer and lower records in autumn/winter. The dominant wind direction was NNW with more than $40 \%$ occurrence and the average wind speed was $4.11 \mathrm{~m} / \mathrm{s}$. The inverse relationship between atmospheric pressure and air temperature was clear. The SST over the study period showed the same seasonal pattern in the air temperature. The mean daily evaporation from AEH surface water follows the pattern of air temperature variations to a considerable extent. The maximum mean monthly evaporation of $14 \mathrm{~cm}(0.14$ $m$ ) occurred in July and August, while the minimum of $6 \mathrm{~cm}(0.06 \mathrm{~m})$ occurred in January. This was associated with a volume loss of $0.389 \times 10^{6} \mathrm{~m}^{3}$ in July and of $0.171 \times 10^{6} \mathrm{~m}^{3}$ in January from AEH surface waters. The solar radiation $\left(Q_{s}\right)$ reached its maximum value in May $\left(383 \mathrm{Wm}^{-2}\right)$ and its lowest value in September $\left(258 \mathrm{Wm}^{-2}\right)$. The net surface heat in $\mathrm{AEH}\left(Q_{\text {net }}\right)$ showed a gain in four successive months: March-June, and a loss in the remaining period: July-September.
\end{abstract}

Keywords: Alexandria Eastern Harbour, meteorological elements, SST, evaporation, surface heat flux

\section{Introduction}

Harbours, natural or man-made, are vulnerable to alterations in weather elements such as air temperature, wind regime, relative humidity and atmospheric pressure. Potential changes in these elements can modify the wave field pattern (Weisse and von Storch 2010), which in turn impacts on the Harbour's activities and may influence its morphology. Also, the interaction between a Harbour's surface waters and the atmosphere controls the heat budget of its water body (Hussein 2019), which in turn regulates the weather in its surroundings and may have impacts on the Harbour's operations (Rusu and Guedes Soares 2013) and, on the long term, on its infrastructures (Sánchez-Arcilla et al. 2016). The sea surface is the lower boundary of the atmosphere, which affects and modifies conditions and status of weather throughout the variations in the sea surface temperature

\footnotetext{
*Associate Research Professor, Laboratory of Physical Oceanography, Division of Marine Environment, National Institute of Oceanography and Fisheries (NIOF), Egypt.
} 
(SST) (Tonbol and El-Geziry 2015). This upper ocean layer is known to be significant for specific oceanographic and climatological applications such as remote sensing, climate modelling, global carbon cycle and heat flux (Laird and Kristovich 2002; Hussein and Mohamed 2016). The latter is crucial to examine numerous scientific applications, e.g., forecasting weather conditions, studying atmospheric circulation, investigating oceanic flows, examining the dynamics of thermal modifications in the lower atmosphere and the upper ocean (Abualnaja 2009).

Several approaches are frequently applied to examine the air-sea interaction and to determine the heat flux. These include the profile method, the eddy correlation method, and the dissipation method (Abualnaja 2009). For a detailed description and explanation of these methods, the reader may refer to Kraus (1972), Pond (1975), and Dobson et al. (1980). Owing to its simplicity, the bulk aerodynamic formulations are a common approach used by many researchers to estimate momentum flux, latent heat flux, and sensible heat flux. These bulk formulas depend on the available weather information (air and dew temperatures in addition to wind regime and cloudiness) and the sea surface temperature.

Alexandria Eastern Harbour (AEH) (Figure 1) is a shallow, protected, semiclosed basin of a semi-circular shape, which is sheltered from the Mediterranean Sea by a breakwater with two openings: El-Boughaz (main central opening) and El-Silsila (side outlet) (El-Geziry and Maiyza 2006; Abdel Salam and Abdel Halim 2008). The southern border of the Harbour has been reinforced and protected by concrete blocks (Hussein 2019). AEH covers the area between Latitudes $31^{\circ} 12^{\prime}$ and $31^{\circ} 12.9^{\prime} \mathrm{N}$, and Longitudes $29^{\circ} 52.0^{\prime}$ and $29^{\circ} 54.4^{\prime} \mathrm{E}$, with a total surface area of about $2.8 \mathrm{~km}^{2}$ (Maiyza and Said, 1988). Historically, AEH is among the most important touristic regions over the world owing to thousands of ancient Egyptian pieces settled at 8-9 $\mathrm{m}$ depth in its north-eastern side (Shaltout et al. 2015; Zaghloul et al. 2020). The seabed in AEH leans steadily from its coastlines to its central part and seawards at El-Boughaz outlet (Maiyza and Said 1988; El-Geziry and Maiyza 2006). The average depth inside AEH is about 5 m, while its maximum depth is about $13 \mathrm{~m}$ close to El-Boughaz (El-Geziry et al. 2007). The water circulation in the Harbour is represented by a two-layer flow system (El-Geziry and Maiyza 2006): a near bottom Mediterranean inflow and a surface seaward flow from the Harbour, through its two outlets. The hydrographic structure of the Harbour was previously studied (Said and Maiyza 1987; Maiyza and Said 1988; El-Geziry and Maiyza 2006). The sea level variation in the Harbour was examined by Alam El-Din et al. (2007); Khedr et al. (2018) and ElGeziry (2020). The circulation and the wave patterns in the vicinity of the Harbour were modelled by Alam El-Din and Abdallah (1998). The air-sea interaction, together with the associated processes and fluxes in AEH, were examined and calculated by El-Geziry (2013); Hussein and El-Geziry (2014); Hussein and Mohamed (2016); Hussein (2017, 2018, 2019).

The present study aims at describing the weather conditions in the surroundings of AEH over two years from 01.01.2019 to 31.12.2020, and to apply the available surface meteorological elements to calculate the sea surface 
temperature, the evaporation rates and the net surface heat flux from the Harbour's surface water.

\section{Data and Methods of Analysis}

The present work covers a two-year period from 01.01.2019 to 31.12.2020. It is based on different data sets collected from different sources. The hourly air temperature in AEH is obtained from the thermal sensor fixed with the new Inexpensive Device for Sea-level Measurement (IDSL) radar system installed at $\left(31.212^{\circ} \mathrm{N}, 29.884^{\circ} \mathrm{E}\right)$ at the National Institute of Oceanography and Fisheries (NIOF) seawall overviewing AHE. This device was installed in the frame of a series of mareographs in the area of the North East Atlantic and Mediterranean Tsunami Warning System (NEAMTWS) (Annunziato 2015). For detailed description of the equipment, its specifications and operation, the reader may refer to (Annunziato 2015; Annunziato et al. 2016).

Figure 1. Alexandria Coastline with its Eastern and Western Harbours

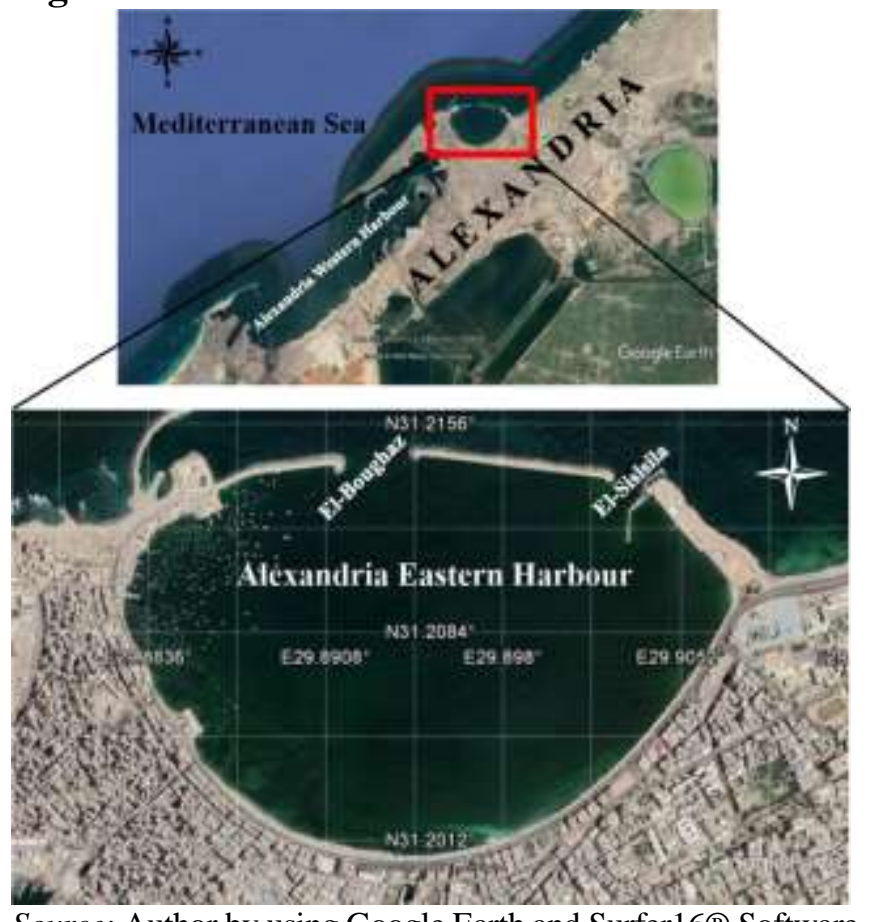

Source: Author by using Google Earth and Surfer16® Software.

The hourly air temperature was downloaded from the website (https://webcri tech.jrc.ec.europa.eu/TAD_server/device/127). These hourly data was averaged daily to get the mean daily air temperature over $\mathrm{AEH}$, used in the calculations of the different applications in the present work.

The hourly wind records: speed $(\mathrm{m} / \mathrm{s})$ and direction $\left({ }^{\circ}\right.$ from True North) were obtained from the meteorological station No. $62318\left(31.22^{\circ} \mathrm{N} ; 29.94^{\circ}\right.$ E) in Alexandria Nozha Airport at about $5 \mathrm{~km}$ far from $\mathrm{AEH}$, from the following 
website: www.ncei.noaa.gov/access/search/data-search/global-hourly?stations $=\% 5 \mathrm{~B} 62318099999 \% 5 \mathrm{D}$.

In addition to the mean daily air temperature, other surface meteorological elements affect the Harbour's surface water. This includes the dew point temperature $\left({ }^{\circ} \mathrm{C}\right)$, the relative Humidity $(\%)$ and the atmospheric pressure $(\mathrm{Hg})$, which were obtained from the same meteorological station from the following website:https://www.wunderground.com/history/monthly/eg/alexandria/HEAX/da te/.

The wind data analysis was performed by the WRPlot view ${ }^{\circledR}$ version 8.02 . Distributions of the mean daily values of the different surface meteorological elements were produced by the Microsoft Excel® 2010.

The applications of the available meteorological data in the present work comprise:

Derivation of the sea surface temperature (SST), which was calculated using Equation (1), derived for the Harbour by El-Geziry (2013).

$$
T_{S S T}=4.7425+0.8445 T_{a}
$$

Where $\mathrm{T}_{\mathrm{SST}}\left({ }^{\circ} \mathrm{C}\right)$ is the daily average $\operatorname{SST}$ and $\mathrm{T}_{\mathrm{a}}\left({ }^{\circ} \mathrm{C}\right)$ is the daily average air temperature.

Calculation of the mean daily evaporation $\left(\mathrm{ET}_{\mathrm{d}} ; \mathrm{mm}\right)$, calculated from the mean daily air temperature $\left(\mathrm{T}_{\mathrm{a}} ;{ }^{\circ} \mathrm{C}\right.$ ) following (Yao and Creed 2005) and (Ghumman et al. 2020):

$$
E T_{d}=0.63 D^{2} \times 10^{\frac{7.5 T_{a}}{T_{a}+273}}
$$

Where $\mathrm{D}$ is the number of the daylight hours, determined by date and latitude. According to Duffie and Beckman (2013), D is calculated with Equation (3):

$$
D=\frac{2}{15} \cos ^{-1}(-\tan (\varnothing) \tan (\delta))
$$

Where $\phi$ is the latitude of the investigated location in the range $-90 \leq \phi \leq+90$, in the present work it is $31.21^{\circ} \mathrm{N}$, and $\delta$ is the solar declination calculated with the following accurate equation (error $<0.035^{\circ}$ ) (Duffie and Beckman 2013):

$$
\begin{gathered}
\delta=\left(\frac{180}{\pi}\right)(0.006918-0.399912 \cos \mathrm{B}+0.070257 \sin \mathrm{B}-0.006758 \cos 2 \mathrm{~B} \\
+0.000907 \sin 2 \mathrm{~B}-0.002697 \cos 3 \mathrm{~B}+0.00148 \sin 3 \mathrm{~B})
\end{gathered}
$$

B is given (Duffie and Beckman 2013) by Equation (5).

$$
B=(n-1) \frac{360}{365}
$$


Where $\mathrm{n}$ is the $\mathrm{n}^{\text {th }}$ day of the year.

Calculation of the daily net surface heat flux $\left(\mathrm{Q}_{\text {net }} ; \mathrm{Wm}^{-2}\right)$ of AEH (Equation 6):

$$
Q_{n e t}=\gamma\left(T_{e}-T_{S S T}\right)
$$

Where $\mathrm{T}_{\mathrm{e}}$ is the equilibrium temperature $\left({ }^{\circ} \mathrm{C}\right.$ ), which is given as (Abualnaja 2009; Hussein and Mohamed 2016):

$$
T_{e}=T_{d p}+\frac{Q_{s}}{\gamma}
$$

Where, $\mathrm{T}_{\mathrm{dp}}$ is the dew point temperature $\left({ }^{\circ} \mathrm{C}\right)$ and $\mathrm{Q}_{\mathrm{S}}$ is the incoming solar radiation per unit area $\left(\mathrm{Wm}^{-2}\right)$. The thermal exchange coefficient $[\gamma]$ is given by Edinger et al. (1974) as a function of sea surface temperature $\left(\mathrm{T}_{\mathrm{SST}} ;{ }^{\circ} \mathrm{C}\right)$ and surface wind speed $(\mathrm{W} ; \mathrm{m} / \mathrm{s})$ :

$$
\gamma=4.5+0.05 T_{S S T}+(\eta+0.47) f(W)
$$

Where $f(W)=3.3 \mathrm{~W}$, and $\eta=0.35+0.015 \mathrm{~T}_{\mathrm{n}}+0.0012 \mathrm{~T}_{\mathrm{n}}^{2}$.

$$
T_{n}=0.5\left(T_{S S T}+T_{d p}\right)
$$

The daily mean values of the incoming solar radiation $\mathrm{Q}_{\mathrm{S}}\left(\mathrm{Wm}^{-2}\right)$ are computed using the following Equation (Reed 1977; Abualnaja 2009):

$$
Q_{S}=Q_{S C}(1-\mu C+0.0019 \beta)(1-A)
$$

Where, $\mathrm{Q}_{\mathrm{sc}}$ is the daily mean values of incoming short-wave radiation $\left(\mathrm{Wm}^{-2}\right) ; \mu$ is a constant taken as 0.62 ; $\mathrm{C}$ is the fractional cloud cover, $\beta$ is the noon solar altitude in degrees, and $\mathrm{A}$ is the albedo.

In latitudes from $20^{\circ} \mathrm{S}$ to $40^{\circ} \mathrm{N}, \mathrm{Q}_{\mathrm{sc}}$ is computed using the formula by Seckel and Beaudry (1973) under clear sky conditions and a suggested albedo of 0.06 (Payne 1972; Abualnaja 2009; Ramu et al. 2010; Hussein and El Geziry 2014). This formula is as follows:

$$
Q_{S C}=A_{0}+A_{1} \cos \theta+B_{1} \sin \theta+A_{2} \cos 2 \theta+B_{2} \sin 2 \theta
$$

Where $A_{s}$ and $B_{s}$ are latitude-dependent coefficients (Reed 1977), and $\theta=(t-$ $21)(360 / 365) ; t$ is the day number. 


\section{Results}

General Distributions of the Recorded Surface Meteorological Elements

Air Temperature

From 01.01.2019 to 31.12.2020, the hourly air temperature varied between $4.0^{\circ} \mathrm{C}$ on 10.01.2019 (04:00 AM) and $44.0^{\circ} \mathrm{C}$ on 23.05.2019 (12:00 noon), with an overall average of $21.4^{\circ} \mathrm{C}$. The mean daily air temperature (Figure 2) fluctuated between $10.2^{\circ} \mathrm{C}$ on 10.01 .2019 and $32.2^{\circ} \mathrm{C}$ on 19.05 .2020 , with an average of $21.6^{\circ} \mathrm{C}$, over the study period. The produced curve reflects a seasonal behaviour in the daily variations, with lower air temperatures in autumn/winter and higher ones in spring/summer seasons.

Figure 2. Mean Daily Air Temperature over AEH during the Period 01.01.201931.12.2020

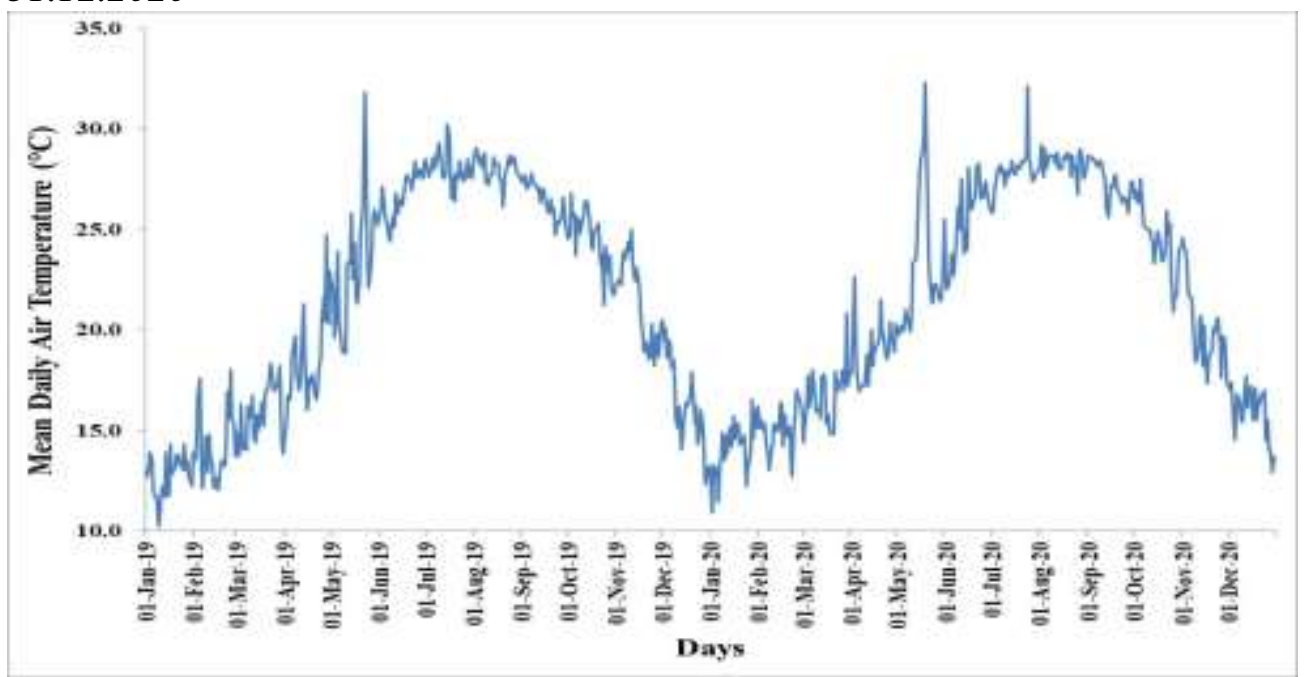

Source: Author.

\section{Wind Regime}

Figures 3 and 4 depict the distributions of the hourly wind direction and speed, respectively, over AEH during the study period. The dominant wind direction was NNW (42\%), and the average wind speed was $4.11 \mathrm{~m} / \mathrm{s}$, with $0 \%$ calm winds. The dominant wind speed class was $(3.6-5.7 \mathrm{~m} / \mathrm{s})$ with $34.8 \%$ frequency of occurrence and the lowest class was that of the speed exceeding $11.4 \mathrm{~m} / \mathrm{s}$ with only $0.2 \%$ frequency of occurrence, over the study period. On the other hand, the mean daily wind speed fluctuated between $1.5 \mathrm{~m} / \mathrm{s}$ on 20.11 .2020 and $17.3 \mathrm{~m} / \mathrm{s}$ on 16.01.2019, with an overall average of $6.5 \mathrm{~m} / \mathrm{s}$ over the period of investigation. 
Figure 3. Wind Rose over AEH during the Period 01.01.2019-31.12.2020

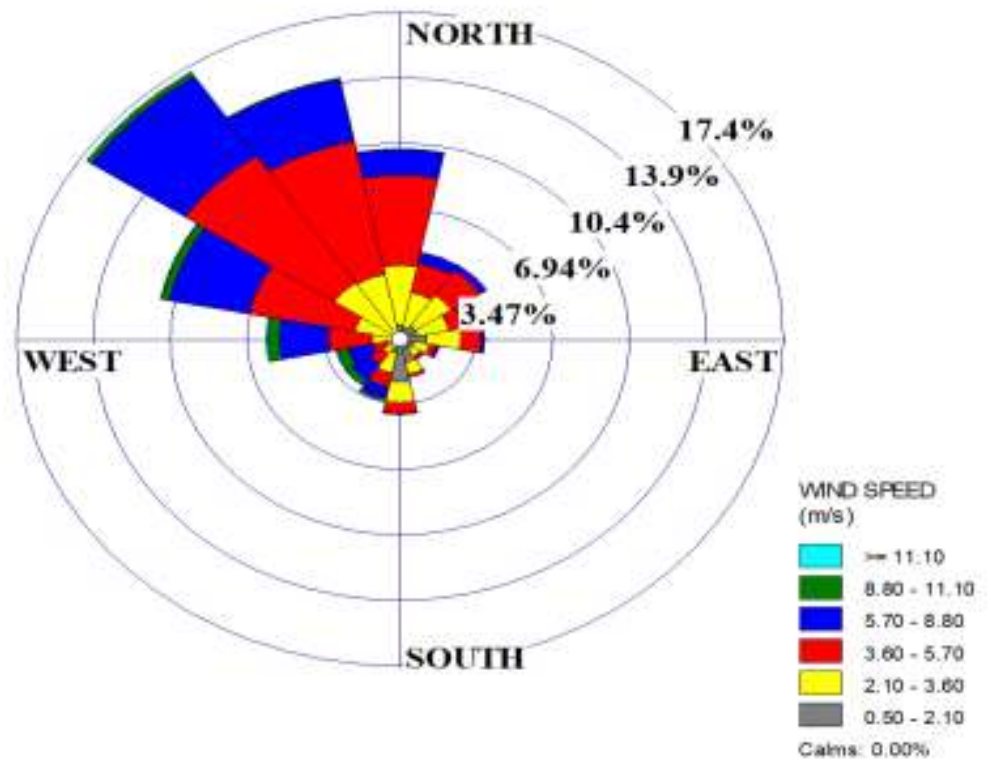

Source: Author.

Figure 4. Wind Speed Frequency Distribution during the Period 01.01.201931.12.2020

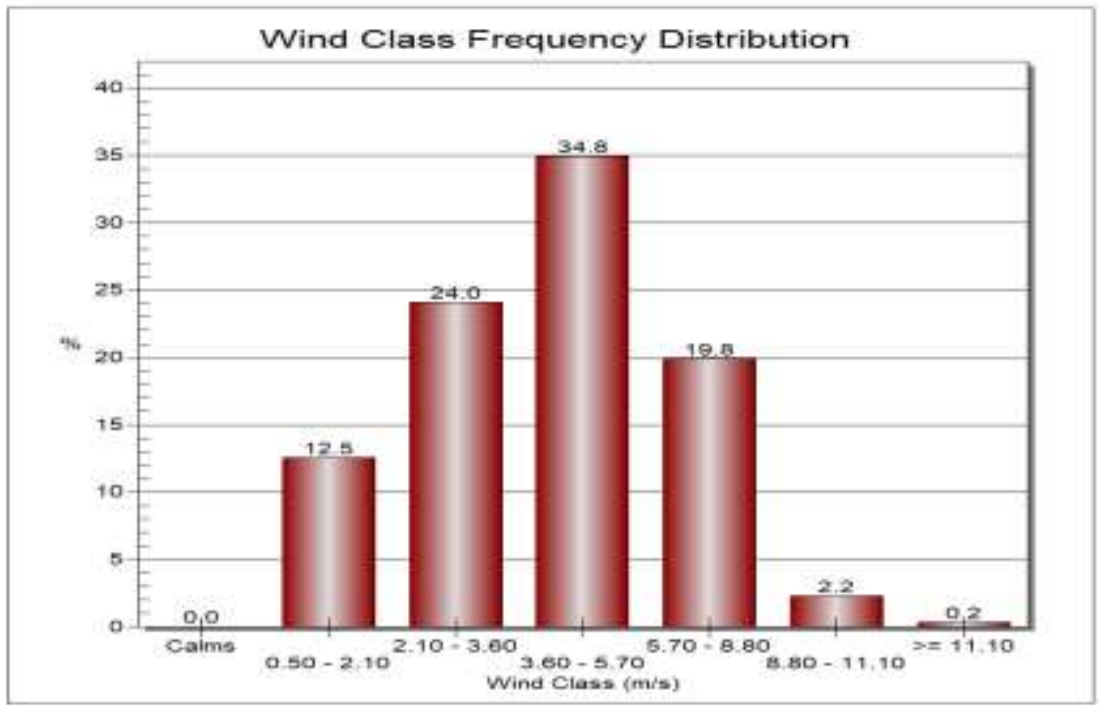

Source: Author.

\section{Dew Point Temperature}

Over the period of investigation, the mean daily dew point temperature fluctuated between a minimum of $1.9^{\circ} \mathrm{C}$ on 25.01 .2019 and a maximum of $24.0^{\circ} \mathrm{C}$ on 03.08.2019, with an overall average of $14.8^{\circ} \mathrm{C}$ (Figure 5). It is clear that the dew temperature pattern of variation follows that of air temperature. 
Figure 5. Mean Daily Dew Point Temperature over AEH during the Period 01.01.2019-31.12.2020

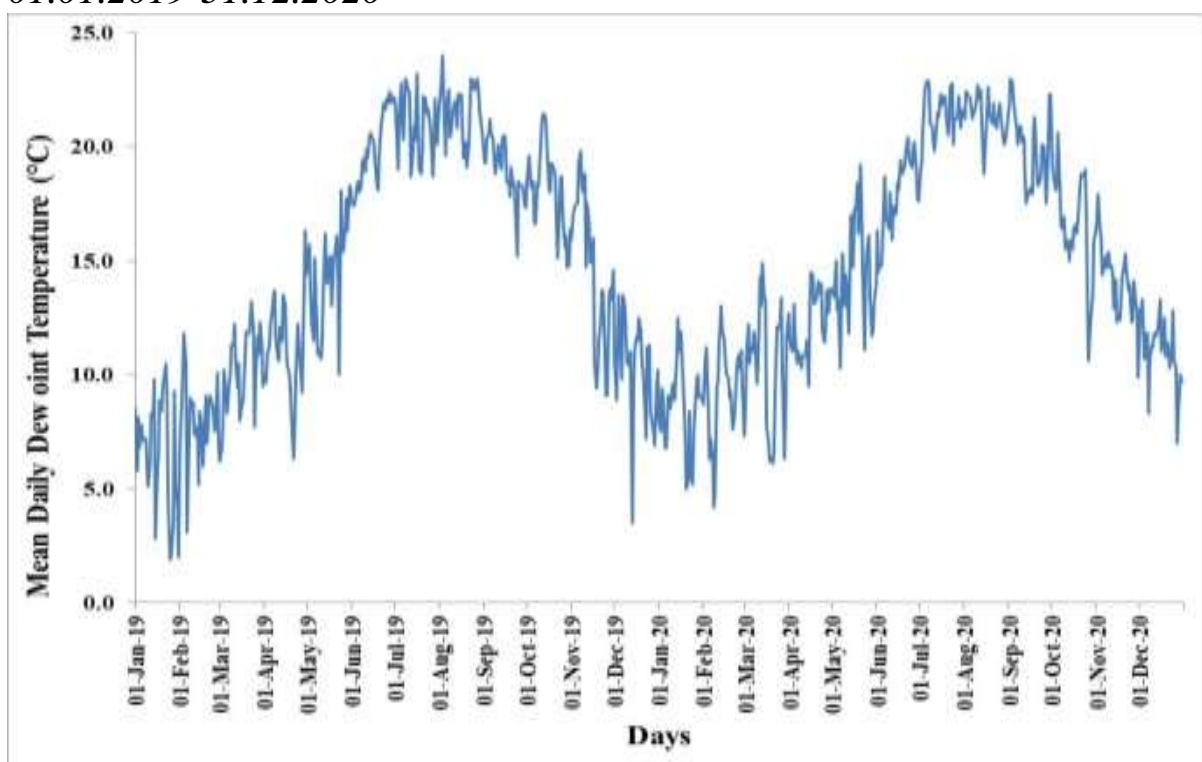

Source: Author.

Relative Humidity

The mean daily relative humidity (Figure 6) ranged between $40.2 \%$ on 23.05.2019 and $88.8 \%$ on 11.03.2020, with an overall average of $67.1 \%$ over the period of investigation.

Figure 6. Mean Daily Relative Humidity over AEH during the Period 01.01. 2019-31.12.2020

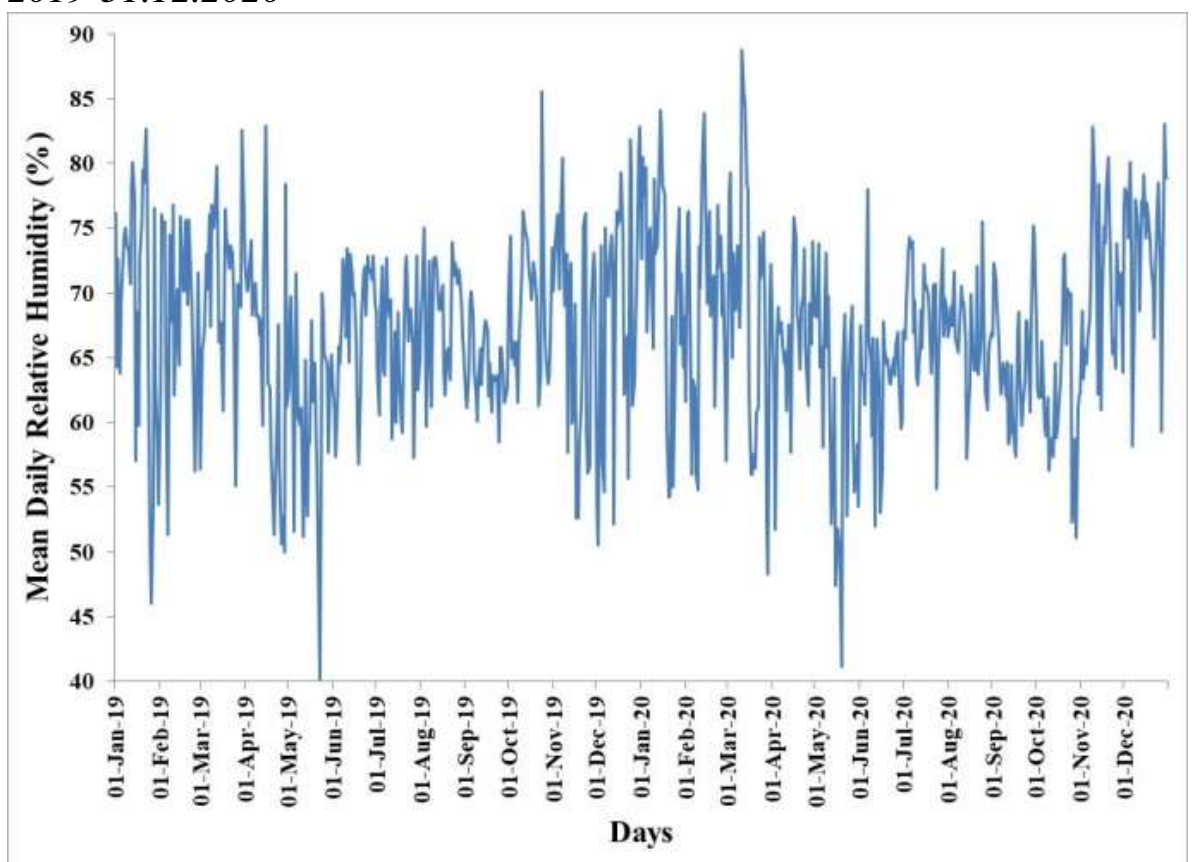

Source: Author. 


\section{Atmospheric Pressure}

The mean daily atmospheric pressure over $\mathrm{AEH}$, during the period of investigation, varied between a minimum of $1003 \mathrm{Hg}$ on 15.07 .2020 and a maximum of $1028 \mathrm{Hg}$ on 24.01.2020, with an average of $1013.04 \mathrm{Hg}$, as shown in Figure 7.

Figure 7. Mean Daily Atmospheric Pressure over AEH during the Period 01.01. 2019-31.12.2020

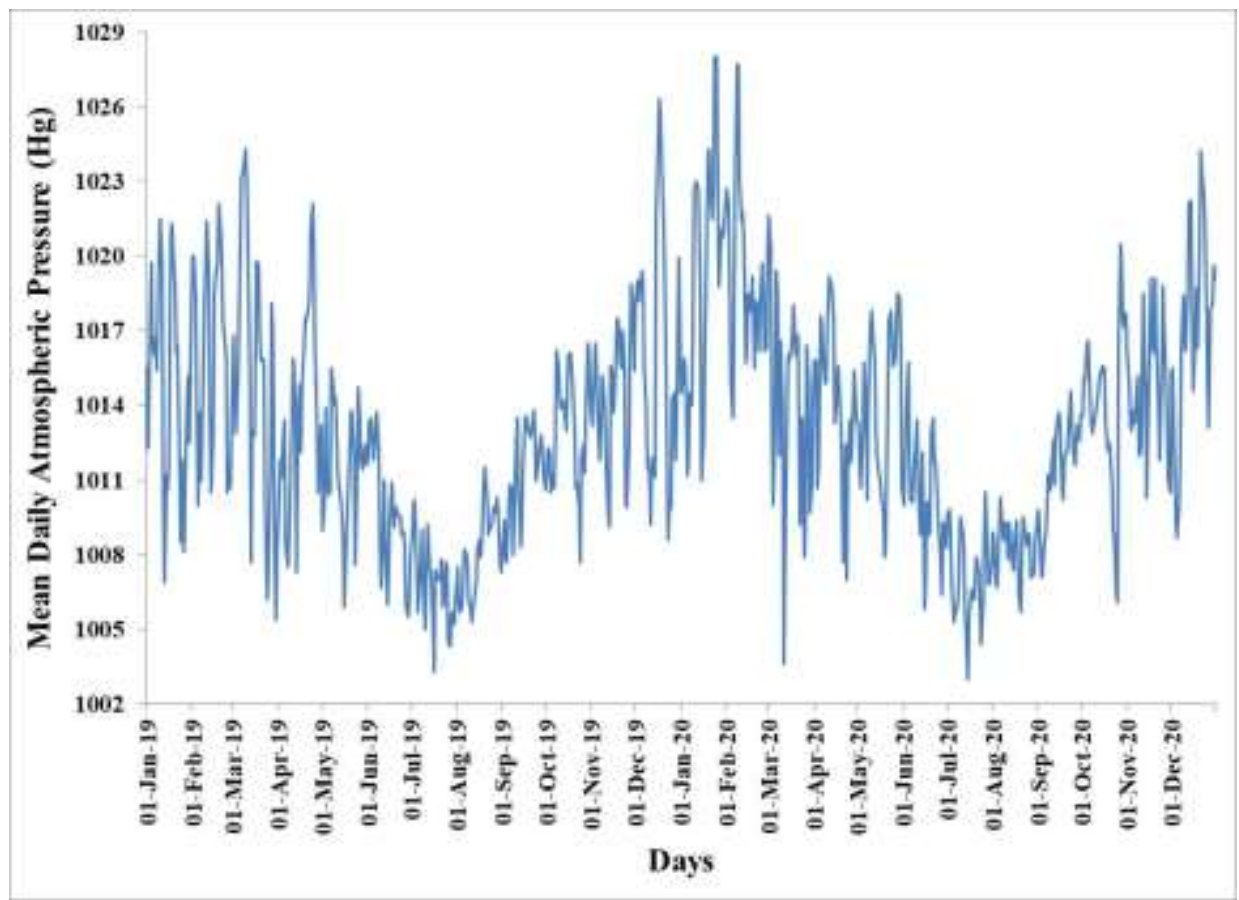

Source: Author.

Applications of the Mean Daily Recorded Surface Meteorological Elements

In the following subsections, three different applications, which depend on the available surface meteorological data, are introduced for the surface water in AEH. This comprises the calculation of the sea surface temperature, the evaporation rates and the net surface heat flux. While the first application is introduced on mean daily basis, the other two are presented on both mean daily and mean monthly basis

\section{Mean Daily Sea Surface Temperature}

Figure 8 depicts the mean daily SST, calculated in the present work based on the calculated mean daily air temperature and by using Equation (1). The mean daily SST over the study period fluctuated between $13.4^{\circ} \mathrm{C}$ on 10.01 .2019 and $32.0^{\circ} \mathrm{C}$ on 19.05 .2020 , with an overall average of $22.9^{\circ} \mathrm{C}$. As previously concluded for the mean daily air temperature, the mean daily SST shows a seasonal pattern of variations, with higher records in spring/summer and lower ones in autumn/winter seasons. 
Figure 8. Mean Daily SST in AEH during the Period 01.01.2019-31.12.2020

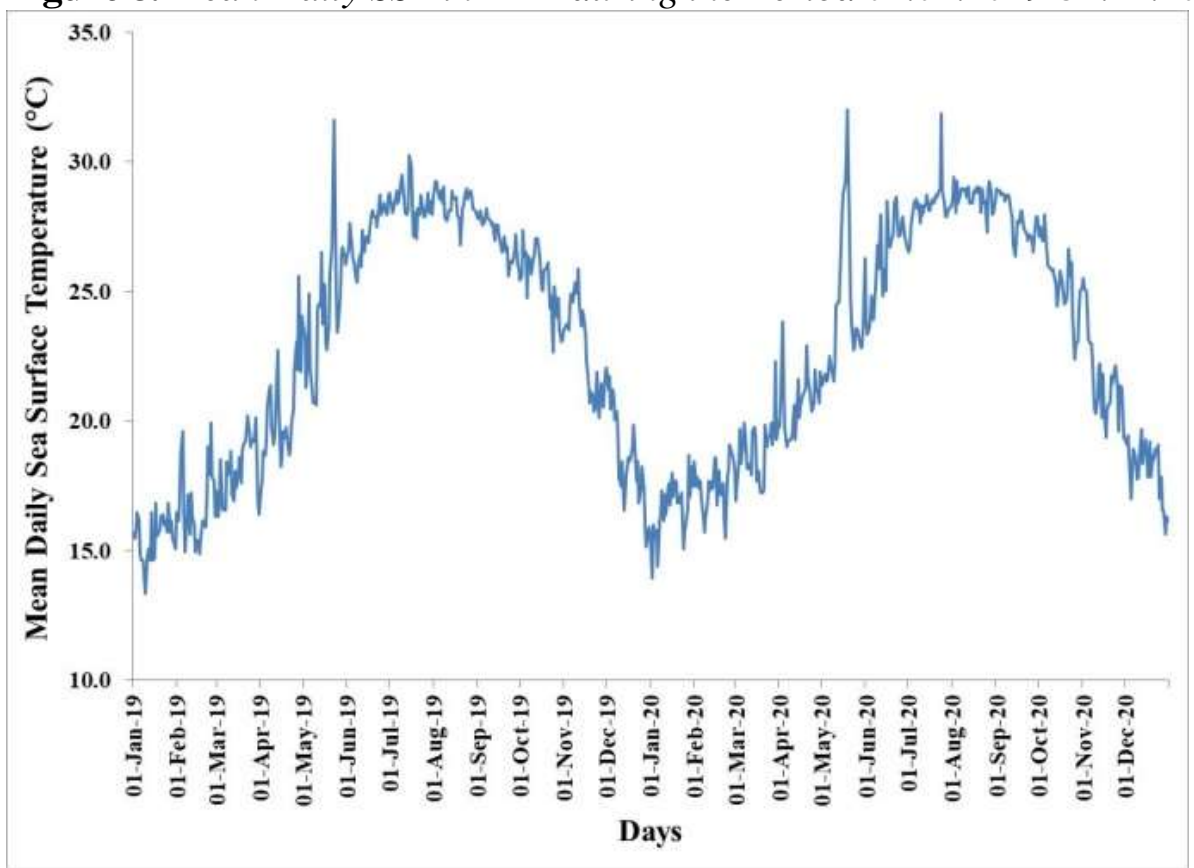

Source: Author.

\section{Evaporation Rates}

The lowest calculated mean daily evaporation rate in $\mathrm{AEH}$ over the period of investigation was $0.40 \mathrm{~mm} / \mathrm{d}$ in 09.03.2019, while the maximum was $2.03 \mathrm{~mm} / \mathrm{d}$ in 08.09.2020, and the overall average was $1.1 \mathrm{~mm} / \mathrm{d}$ (Figure 9). Table 1 shows the estimated mean monthly evaporation from AEH surface water. It can be easily detected that the higher evaporation rates occur in summer and the lower ones in winter. The maximum mean monthly evaporation of $14 \mathrm{~cm}$ occurred in July and August, while the minimum of $6 \mathrm{~cm}$ occurred in January. The associated volume loss from AEH surface water due to the evaporation also had a maximum value of $0.389 \times 10^{6} \mathrm{~m}^{3}$ in July and a minimum of $0.171 \times 10^{6} \mathrm{~m}^{3}$ in January.

\section{Net Surface Heat Flux}

Unfortunately, there is no data available on cloudiness and its fractions (either oktas or tens) over AEH. Therefore, and to represent accurate results reflecting the actual situation, and to confidently fulfil the clear sky condition in Equation (10) from which we get the incoming solar radiation, the calculations in the present work will be made only for the periods representing the spring and the summer seasons, i.e., from $21^{\text {st }}$ March to $20^{\text {th }}$ September. The mean monthly heat flux exchange at the air-sea interface $\left(Q_{s}\right)$ for the examined period shows a heat gain over the different months of interest (Table 2). The net surface heat in $A E H\left(Q_{\text {net }}\right)$ shows a gain in four successive months: March-June, and a loss in the remaining period: July-September. 
Figure 9. Mean Daily Evaporation in AEH during the Period 01.01.201931.12.2020

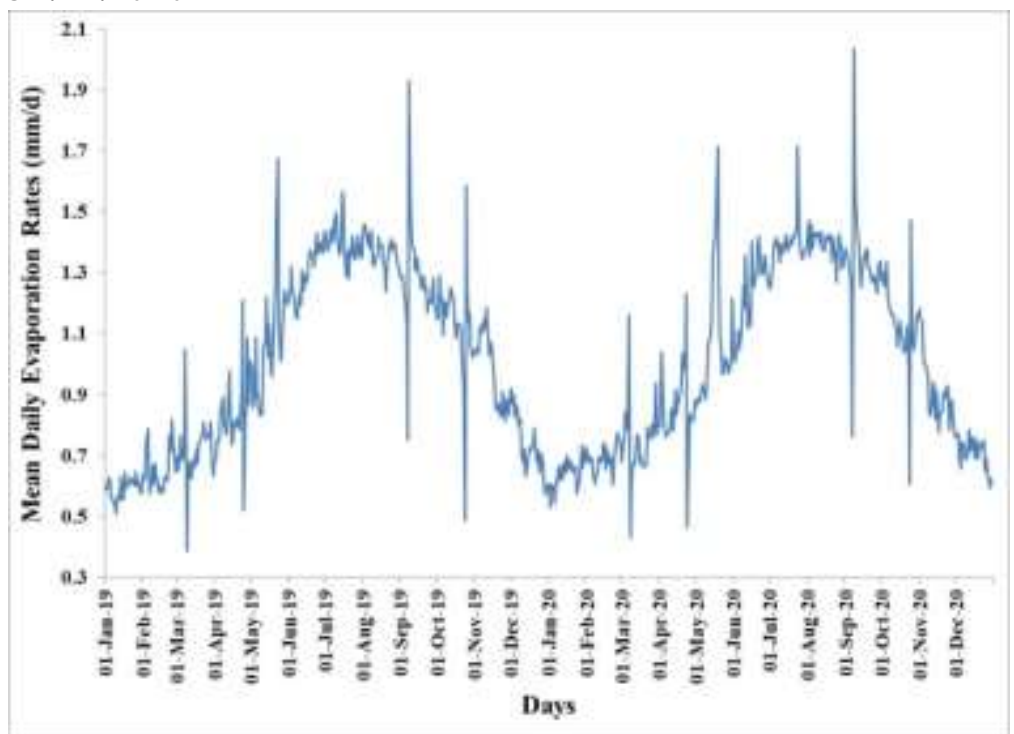

Source: Author.

Table 1. Mean Monthly Evaporation Rates and Volume Loss from AEH Surface Waters

\begin{tabular}{|l|c|c|}
\hline & Evaporation Rate $\mathbf{( m} / \mathbf{m o n t h})$ & Surface Volume Loss $\left.\mathbf{( x 1 0}^{\mathbf{6}} \mathbf{~ m}^{\mathbf{3}}\right)$ \\
\hline January & 0.06 & 0.171 \\
\hline February & 0.07 & 0.188 \\
\hline March & 0.07 & 0.204 \\
\hline April & 0.08 & 0.235 \\
\hline May & 0.11 & 0.299 \\
\hline June & 0.13 & 0.356 \\
\hline July & 0.14 & 0.389 \\
\hline August & 0.14 & 0.386 \\
\hline September & 0.13 & 0.367 \\
\hline October & 0.11 & 0.319 \\
\hline November & 0.10 & 0.266 \\
\hline December & 0.07 & 0.202 \\
\hline
\end{tabular}

Source: Author.

Table 2. Monthly Means Values of the Different Parameters Contributing in the Calculation of the Net Surface Heat Flux in AEH

\begin{tabular}{|l|c|c|c|c|c|c|c|}
\hline & $\begin{array}{c}\mathbf{T}_{\mathbf{d p}} \\
\left({ }^{\circ} \mathbf{C}\right)\end{array}$ & $\begin{array}{c}\mathbf{S S T} \\
\left({ }^{\circ} \mathbf{C}\right)\end{array}$ & $\begin{array}{c}\mathbf{W S} \\
\left(\mathbf{m s}^{-1}\right)\end{array}$ & $\begin{array}{c}\boldsymbol{\gamma} \\
\left(\mathbf{W . m}^{\mathbf{2}} \cdot{ }^{\circ} \mathbf{C}\right)\end{array}$ & $\begin{array}{c}\mathbf{Q}_{\mathbf{s}} \\
\left(\mathbf{W m}^{-2}\right)\end{array}$ & $\begin{array}{c}\mathbf{T}_{\mathbf{e}} \\
\left({ }^{\circ} \mathbf{C}\right)\end{array}$ & $\begin{array}{c}\mathbf{Q}_{\text {net }} \\
\left(\mathbf{W m}^{-2}\right)\end{array}$ \\
\hline March & 10.3 & 18.5 & 6.8 & 34.2 & 309 & 20.3 & 30 \\
\hline April & 11.7 & 20.5 & 6.5 & 35.1 & 357 & 22.6 & 50 \\
\hline May & 14.5 & 24.3 & 6.3 & 38.5 & 383 & 25.0 & 12 \\
\hline June & 19.0 & 26.8 & 6.4 & 43.4 & 387 & 28.1 & 48 \\
\hline July & 21.2 & 28.4 & 7.3 & 52.5 & 366 & 28.5 & -7 \\
\hline August & 21.5 & 28.5 & 6.7 & 48.8 & 320 & 28.3 & -27 \\
\hline September & 19.5 & 27.5 & 6.8 & 47.0 & 258 & 25.2 & -115 \\
\hline
\end{tabular}

Source: Author. 


\section{Discussion}

Temporal variations (daily, monthly, seasonal and interannual) of natural climate in mid-latitude regions are sensitive to the SST distribution and its variability (Webster 1994; Kawamura et al. 2008). The SST variations themselves are mainly regulated by variations in the air-sea heat flux in addition to the vertical mixing and the horizontal advection of heat (Skliris et al. 2012). Hence, the surface meteorological elements, namely: air temperature, wind regime (speed and direction), dew point temperature, relative humidity and atmospheric pressure, are considered in the present work to describe the general meteorological conditions over one important Harbour in Alexandria: Alexandria Eastern Harbour. These conditions are then applied in the calculations of important physical properties of the Harbour's surface waters, including: the SST, the evaporation rates and the net surface heat flux. The period of investigation extended from 01.01.2019 to 31.12.2020.

The air temperature distribution over AEH reflects a seasonal variability with higher values in spring/summer and lower records in autumn/winter. January and May were the months of lowest and highest daily temperature, respectively. This is in agreement with the results of Mohamed and Beltagy (2009) that showed the same months while investigating the long-term air temperature in Alexandria. The dominant wind direction during the study period was NNW with more than $40 \%$ occurrence, and the average wind speed over the period of investigation was 4.11 $\mathrm{m} / \mathrm{s}$. This is in consistent with the known wind regime of Alexandria, e.g., Alam El-Din and Abdallah (1998) declared dominant NNW over AEH during the year 1979; El-Geziry (2013) declared 49\% occurrence for the NNW wind and average speed of $4.17 \mathrm{~m} / \mathrm{s}$ over two years (2005-2006); Khedr et al. (2018) showed a NW prevailing wind over AEH with $11.9 \%$ occurrence in 1996. The inverse relationship between atmospheric pressure and air temperature is proved in the present work as shown in Figures 2 and 7. The mean daily SST fluctuated between $13.4^{\circ} \mathrm{C}$ on 10.01 .2019 and $32.0^{\circ} \mathrm{C}$ on 19.05 .2020 , with an overall average of $22.9^{\circ} \mathrm{C}$, showing the same seasonal pattern of variation detected for the air temperature. The mean daily evaporation from AEH surface water follows the pattern of air temperature variations to a considerable extent. The lowest mean daily evaporation rate in AEH was in March $2019(0.40 \mathrm{~mm} / \mathrm{d})$, while the maximum was in September 2020 (2.03/d mm). According to Romanou et al. (2010), the maximum evaporation in the Levantine Bain is $4 \mathrm{~mm} / \mathrm{d}$. The overall average of mean daily evaporation over the period of investigation was $1.1 \mathrm{~mm} / \mathrm{d}$. This is in agreement with the average rate of $1.6 \mathrm{~mm} / \mathrm{d}$ calculated for the eastern Mediterranean (Shaltout and Omstedt 2012) but meanwhile, lower than that of 2.5 $\mathrm{mm} / \mathrm{d}$ in AEH by Hussein (2019) for the period from 06.06.2010 to 16.02.2011. This difference may be attributed to the different length in the period of investigation in the two studies. Furthermore, the mean monthly evaporation rates have a seasonal pattern of variation; being low in winter months and high in summer months. The present monthly rates $(\mathrm{m} / \mathrm{month})$ are in agreement with those previously concluded for the eastern Mediterranean basin (Colacino and Dell'Osso 1977; Shaltout and Omstedt 2012) as shown in Table 3. 
Table 3. Comparison between the monthly rates of evaporation ( $\mathrm{m} / \mathrm{month}$ ) in AEH and in the Eastern Mediterranean Basin

\begin{tabular}{|l|c|c|c|}
\hline & $\begin{array}{c}\text { Present } \\
\text { Study }\end{array}$ & $\begin{array}{c}\text { Colacino and Dell'Osso } \\
(\mathbf{1 9 7 7})\end{array}$ & $\begin{array}{c}\text { Shaltout and Omstedt } \\
(\mathbf{2 0 1 2})\end{array}$ \\
\hline January & 0.06 & 0.13 & 0.09 \\
\hline February & 0.07 & 0.11 & 0.08 \\
\hline March & 0.07 & 0.10 & 0.07 \\
\hline April & 0.08 & 0.07 & 0.05 \\
\hline May & 0.11 & 0.08 & 0.06 \\
\hline June & 0.13 & 0.11 & 0.08 \\
\hline July & 0.14 & 0.18 & 0.11 \\
\hline August & 0.14 & 0.19 & 0.12 \\
\hline September & 0.13 & 0.19 & 0.11 \\
\hline October & 0.11 & 0.15 & 0.11 \\
\hline November & 0.10 & 0.13 & 0.11 \\
\hline December & 0.07 & 0.13 & 0.11 \\
\hline
\end{tabular}

Source: Author and Cited References.

The heat flux exchange at the sea-air boundary can be assessed in term of the thermal exchange coefficient $\gamma\left(\mathrm{W} \cdot \mathrm{m}^{2} .{ }^{\circ} \mathrm{C}\right)$ and the equilibrium temperature $\mathrm{T}_{\mathrm{e}}\left({ }^{\circ} \mathrm{C}\right)$; using surface meteorological elements and sea surface temperature (Abualnaja 2009). Accordingly, the net surface heat flux $Q_{\text {net }}$ in $A E H$ is calculated in the present study. The solar radiation $\left(\mathrm{Q}_{\mathrm{s}}\right)$ reached its maximum value in May (383 $\left.\mathrm{Wm}^{-2}\right)$ and its lowest value in September $\left(258 \mathrm{Wm}^{-2}\right)$. The correlation between the thermal exchange coefficient $\gamma\left(\mathrm{W} \cdot \mathrm{m}^{2} .{ }^{\circ} \mathrm{C}\right)$ and the wind speed in the investigated months of spring and summer seasons is positive $(+0.6)$ and is negative $(-0.6)$ with the $\mathrm{Q}_{\text {net. }}$ This agrees with the conclusions of Hussein and Mohamed (2016). On the other hand, the correlation between the net surface heat flux $\left(\mathrm{Q}_{\text {net }}\right)$ and the difference between $T_{e}$ and $T_{S S T}$ is high $(+0.97)$, which is in agreement with the conclusion of Hussein and Mohamed (2016).

\section{Conclusion}

To conclude, the surface meteorological elements in the present study are in consistent with those previously examined in Alexandria over different periods. These elements are useful for many applications especially those concerning the air-sea interaction processes. In this paper; the net rate of total heat flux at the airsea interface was evaluated in terms of the thermal exchange coefficient and the equilibrium temperature, which represents a straightforward method to calculate the net heat flux exchange at the water surface in $\mathrm{AEH}$. 


\section{References}

Abdel Salam KhM, Abdel Halim AM (2008) Influence of colour of substratum on the marine fouling communities at the Eastern Harbour (Alexandria, Egypt). Egyptian Journal of Aquatic Research 34(Nov): 126-143.

Abualnaja Y (2009) Estimation of the net surface heat flux in the Arabian Gulf based on the equilibrium temperature. Journal King Abdul-Aziz University: Marine Sciences 20(1): 21-29.

Alam El-Din KA, Abdallah MA (1998) High resolution simulation of the water movement in the Eastern Harbor of Alexandria, Egypt. In International Conference on Coastal and Ocean Modelling, Malta.

Alam El-Din KA, Abdelrahman SM, El-Meligy M (2007) Seasonal and long term variations of sea level and meteorological conditions along the Egyptian coasts. In $8^{\text {th }}$ International Conference on the Mediterranean Coastal Environment (MEDCOAST), 1295-1307.

Annunziato A (2015) The inexpensive device for sea level measurements. Journal of Tsunami Society International 34(4): 199-211.

Annunziato A, Galliano D, Bonaita M (2016) IDSL sea level measurement devices. Luxembourg.

Colacino M, Dell'Osso L (1977) Monthly mean evaporation over the Mediterranean Sea. Archiv für Meteorologie Geophysik und Bioklimatologie A 26(Jun): 283-293.

Dobson F, Hasse L, Davis R (1980). Air-sea interaction instruments and methods. Plenum Press.

Duffie JA, Beckman WA (2013) Solar engineering of thermal processes. New Jersey: Wiley Press.

Edinger JE, Brady DK, Geyer JC (1974) Heat exchange and transport in the environment. Report No. 14, Cooling Water Discharge Research Project (RP-49), USA.

El-Geziry TM (2013) On the diurnal variations of in-situ sea surface temperature (SST) in Alexandria Eastern Harbour, Egypt. Journal of Operational Oceanography 6(2): 18.

El-Geziry TM (2020) Sea-level, tides and surges in Alexandria Eastern Harbour. The Egyptian Journal of Aquatic Research. [In Press] https://doi.org/10.1016/j.ejar.20 20.10.003.

El-Geziry TM, Maiyza IA (2006) Hydrographic structure of Alexandria Eastern Harbor. Egyptian Journal of Aquatic Research 32(Jan): 60-73.

El-Geziry TM, Abd Ellah RG, Maiyza IM (2007). Bathymetric chart of Alexandria Eastern Harbor. Egyptian Journal of Aquatic Research 33(1): 15-21.

Ghumman AR, Ghazaw YM, Alodah A, Rauf A, Shafiquzzaman Md, Haider H (2020) Identification of parameters of evaporation equations using an optimization technique based on pan evaporation. Water 12(1): 228.

Hussein MMA (2017) Effectiveness of unstable atmospheric boundary layer on heat loss from Alexandria Eastern Harbor, Egypt. International Journal of Innovative Science, Engineering \& Technology 4(8): 242-247.

Hussein MMA (2018) Evaluation of Alexandria Eastern Harbor evaporation estimate methods. Arabian Journal of Geosciences 11(24): 768.

Hussein MMA (2019) Impact of atmospheric stability conditions on heat fluxes from Alexandria Eastern Harbor, Egypt. Egyptian Journal of Aquatic Research 45(4): 313-319. 
Hussein MMA, El Geziry TM (2014) Diurnal variability of heat fluxes and Bowen Ratio over Alexandria Eastern Harbor, Egypt. Journal King Abdul-Aziz University: Marine Sciences 25(2): 57-85.

Hussein MMA, Mohamed E (2016) Estimation of net surface heat flux of eastern harbor, alexandria egypt using different techniques. Advances in Research 7(3): 1-12.

Kawamura H, Qin H, Ando K (2008) In-situ diurnal sea surface temperature variations and near-surface thermal structure in the tropical hot event of the Indo-Pacific warm pool. Journal of Oceanography 64(Nov): 847-857.

Khedr AM, Abdelrahman SM, Alam El-Din KA (2018) Currents and sea level variability of Alexandria coast in association with wind forcing. Journal King Abdul-Aziz University: Marine Sciences 28(2): 27-42.

Kraus EB (1972) Atmosphere-ocean interaction. Oxford, UK: Claredon Press.

Laird NF, Kristovich DAR (2002) Variations of sensible and latent heat fluxes from a great lakes buoy and associated synoptic weather patterns. Journal of Hydrometeorology 3(1): 3-12.

Maiyza IA, Said MA (1988) The time variation of temperature, salinity and oxygen content in the Eastern Harbour of Alexandria. Bulletin of Institute of Oceanography \& Fisheries 14(1): 67-74.

Mohamed EE, Beltagy AI (2009) Analysis of long-term air temperature in Alexandria. Egyptian Journal of Aquatic Research 35(4): 461-474.

Payne RE (1972) Albedo of the sea surface. Journal of Atmospheric Science 29(Jul): 959970.

Pond S (1975) The exchange of momentum, heat and moisture at the ocean-atmosphere interface in Numerical models of ocean circulation. In Proceedings of the Symposium, National Academy of Sciences, 26-28. Washington D.C., USA.

Ramu CV, Bharathi G, Sadhuram Y (2010) Diurnal variability of heat fluxes over the coastal waters off Visakhapatnam during post-monsoon and winter seasons. Indian Journal of Marine Sciences 39(1): 128-135.

Reed RK (1977) On estimating insolation over the ocean. Journal of Physical Oceanography 7(May): 482-485.

Romanou A, Tselioudis G, Zerefos CS, Clayson C, Curry J, Andersson A, et al (2010) Evaporation-Precipitation variability over the Mediterranean and the Black Seas from satellite and reanalysis estimates. Journal of Climate 23(19): 5268-5287.

Rusu L, Guedes Soares C (2013) Evaluation of a high-resolution wave forecasting system for the approaches to ports. Ocean Engineering 58(Jan): 224-238.

Said MA, Maiyza IA (1987) Effect of the domestic sewage discharge on the hydrographic regime of the Eastern Harbour of Alexandria. Bulletin of Institute of Oceanography \& Fisheries 13: 1-20.

Sánchez-Arcilla A, Sierra JP, Brown S, Casas-Prat M, Nicholls RJ, Lionello P, et al (2016) A review of potential physical impacts on harbours in the Mediterranean Sea under climate change. Regional Environmental Change 16(8): 2471-2484.

Seckel GR, Beaudry FH (1973) The radiation from sun and sky over the North Pacific Ocean. EOS-Trans American Geophysical Union 54(Mar): 1114.

Shaltout M, Omstedt A (2012) Calculating the water and heat balances of the Eastern Mediterranean Basin using ocean modelling and available meteorological, hydrological and ocean data. Oceanologia 54(2): 199-232.

Shaltout M, Tonbol K, Omstedt A (2015) Sea-level change and projected future flooding along the Egyptian Mediterranean coast. Oceanologia 57(4): 293-307.

Skliris N, Sofianos S, Gkanasos A, Mantziafou A, Vervatis VD, Axaopoulos P, et al (2012) Decadal scale variability of sea surface temperature in the Mediterranean Sea in relation to atmospheric variability. Ocean Dynamics 62(1): 13-30. 
Tonbol KM, El-Geziry TM (2015) The daily SST variations within the South Eastern Mediterranean Sea. In the $12^{\text {th }}$ International Conference on the Mediterranean Coastal Environment (MEDCOAST15), 1005-1016. Bulgaria.

Webster PJ (1994) The role of hydrological processes in ocean-atmosphere interactions. Reviews of Geophysics 32(4): 427-476.

Weisse R, von Storch H (2010) Marine climate and climate change: storms, wind, waves and storm surges. Chichester, UK: Springer Praxis Publishing.

Yao H, Creed IF (2005) Determining spatially-distributed annual water balances for ungauged locations on Shikoku Island, Japan: a comparison of two interpolators. Hydrological Sciences Journal 50(2): 245-263.

Zaghloul FA-R, Khairy HM, Hussein NR (2020) Assessment of phytoplankton community structure and water quality in the Eastern Harbor of Alexandria, Egypt. Egyptian Journal of Aquatic Research 46(2): 145-151. 